\title{
Evaluation of Different Fungicides Against Phytophthora Spp. Associated with Citrus Decline: A Review
}

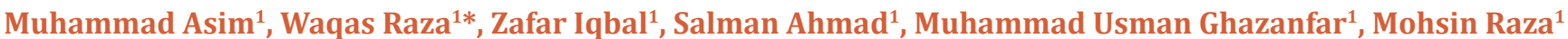 \\ and Muhammad Adnan²
}

${ }^{1}$ Department of Plant Pathology, College of Agriculture, University of Sargodha, Punjab, 40100, Pakistan

${ }^{2}$ Department of Agronomy, College of Agriculture, University of Sargodha, Sargodha, 40100, Pakistan

Submission: May 10, 2019; Published: June 13, 2019

"Corresponding author: Waqas Raza, Department of Plant Pathology, College of Agriculture, University of Sargodha, 40100, Pakistan

\begin{abstract}
There are several ways to manage plant diseases like use of resistant varieties, biological control agents, plant extracts, use of synthetic chemicals and integrated plant disease management. Among them, use of chemicals is most practised and easy way to manage plant diseases. There are many fungicides available in the market for this purpose. Fungicide like metalaxyl and mancozeb are effective to inhibit mycelial growth of Phytophthora vignae that causes root rot of cowpea. Fosetyl-Al gives good control against Phytophthora root rot when apply as foliar spray, sleeve drench to seedling or trunk injection to mature tree. Copper based fungicides completely inhibit the myceilal growth of fungi belong to class oomycetes. Mixture of mancozeb and fenamidone as well as copper octanoate and dimethomorph are effective to control Phytophthora ramorum.
\end{abstract}

Keywords: Citrus; Disease; Management; Fungicide; Effective

\section{Introduction}

Citrus is one of the most important fruit crops of the world that belongs to family Rutaceae, comprises of 130 genera and seven subfamilies [1]. It is cultivated in tropical and subtropical region of the world in near about 140 countries. It is thought that citrus were originated from china and other eastern region like Thailand, Malaysia and India. In Middle East, Europe, North Africa, turkey and Greece it was introduced by Alexander from India in fourth century $\mathrm{BC}$ [2]. With the passage of time citrus occupying all the continents, societies and cultures due to its lush green tree, beautiful flower and delicious fruit. Now a day's world annual citrus production is near about 115 million tons. Brazil is at the top with more than 20 million tons production, China ranked second with 19.6 million tons and United States is the third largest producer with 10 million tons. Other important citrus producing countries are Mexico, India, Spain, Iran, Nigeria and Turkey [3] Major grown verities of citrus are oranges, mandarins, lime, and grapefruits. There are many cultivar of citrus available to grow but it is mainly classified into oranges, mandarins, tangerines, sour oranges, lemons, limes, grapefruit, pummelos and citron. Citrus is full of nutritional benefits, it is source of vitamin-C which help in absorption of iron, zinc and other foods. As compared to other fruits, citrus has higher contents of antioxidants which catalysed our immune system and also protects us from heart diseases and cancer. Citrus fruit contains good quantity of dietary fibre which improves food digestion and protect from constipation. Low level of sodium and high content of potassium are good to maintain normal blood pressure. Rich source of phytochemicals which protect human body from cancer, blood clotting and heart diseases as well as have anti-inflammatory properties. Flavonoids which are good against allergies, viral and fungal infection, inflammatory and heart diseases are also component of citrus fruit. Folate is a component of citrus fruit which helps in genetic stability and protect children from neural tube problem. Citrus fruit is good source of polyphenols which are good against viral infection and have anti-carcinogenic, anti-proliferative and anti-inflammatory properties [4].

\section{Evaluation of Fungicides}

Young et al. conducted experiments in USA, Australia and South Africa to manage Phytophthora root rot of avocado tree. Fosetyl-Al and phosphorous acid were applied through injection, sleeve drench and foliar spray. There were significant difference in result of Fosetyl-Al and phosphorous acid application. In South Africa fosetyl-al injection gave better result as compared to folia spray. There was improvement in affect when calcium buffer were used with Fosetyl-al. In case of phosphorous acid there 
was decline after improvement in the start, Fosetyl-al treatment give significant recovery. In Australia there was 48\% improve maintain plant health when Fosetyl-Al was used at $15 \mathrm{ml} / \mathrm{m}$ of tree canopy for two times in period of 5 months. Response of Fosetyl-Al improved when zinc sulfate salt was added. In Florida and California result indicated that foliar spray was better than sleeve drench. Overall results indicated that Fosetyl-Al is effective in controlling Phytophthora root rot either applied by using sleeve drench, injection or foliar spray.

Fernando [5] evaluated metalaxyl, mancozeb, aliette and etridiazole fungicidesto control Phytophthora vignae which causes root and stem rot of cowpea. P001\& P006 isolates of P. vignae were used. Metalaxyl gave maximum control under lab condition and in pot experiments. Inhibition of oogonia was also maximum in plates amended with metalaxyl. In greenhouse experiments there were no aerial symptoms on plants treated with metalaxyl. Dry shoot weight of non-inoculated control and plants treated with metalaxyl at rate of $10 \mathrm{mg}$ per litter was same, but roots dry weight was higher in plants treated with metalaxyal. Root disease severity was minimum when metalaxyl used at the rate of $100 \mathrm{mg} / \mathrm{L}$. Similar result were produced in stem disease severity control when alliete and mancozeb were used at the rate of $1000 \mathrm{mg} / \mathrm{L} \& 100 \mathrm{mg} / \mathrm{L}$ respectively. Mancozeb were most effective when used as drench as compared to foliar spray. Etridiazole gave same result at $50 \mathrm{mg} / \mathrm{L}$ as metalaxyl give at $10 \mathrm{mg} / \mathrm{L}$.

Lamour KH [6] discussed ethology of diseases affecting floriculture crops caused by Phytophthora parasitical and P. Drechsler. For isolation of pathogens samples were collected from 11 different production bases on the bases of apparent symptoms. Pathogen was isolated on BARP media. For purification a plug from colony shifted to petri plate containing water agar. Pathogen was identified to species level on the basis of morphological character, and sequencing of ribosomal DNA. These characters revealed that these were the isolates of $P$. drecsleri and P.nicotianae. There was genetic diversity among the isolates. In 68 markers from P. nicotianae 42 were monomorphric and 26 were polymorphric. Among the 64 AFLP markers from P. drechsleri 30 were monomorphic and 34 were polymorphic.

Wagner S [7] evaluated different fungicides to control Phytophthora ramorum causes disease in oak plant. Pathogen was isolated in Europe and USA from nurseries and plant grown in natural habitat. Nine fungicides were used, each fungicide were tested at seven different concentrations. Combination of mancozeb and fenamidone, copper-octanoate and dimethomorph gave most significant result as they completely inhibited mycelial growth and zoospore germination. On the other hand, propamocarb, azoxystrobin and cyzofamid were least effective in zoospores germination and mycelial growth germination.

$\mathrm{Hu} \mathrm{JH}$ [8] isolated from nurseries in Virginia, USA and evaluated mefenoxam sensitivity against it. More than 90 isolates that were isolated from nurseries of different crops and irrigated water in Virginia was used. Different isolates that were isolated from other crops were used for comparison. Fungicides were evaluated at the rate of $100 \mathrm{ug} / \mathrm{mL}$ and then added to growth media at $50^{\circ} \mathrm{C}$. Small agar disc containing pathogen was placed in the centre of perti dish containing poisoned media. Three replicate were used for each treatment. After inoculation plates were incubated for 5-7 days at $23^{\circ} \mathrm{C}$ in dark. Growth inhibition was measured after 7 days. For pot experiments, 7 sensitive and 9 resistant isolates were selected. After treatments with fungicides seedlings of geranium plants were inoculated with Phytophthora nicotianae. Mefenonam gave complete protection to seedling against sensitive isolates but mortality rate was same in non- treated control and plants treated with resistant isolates.

Tjosvold SA [9] evaluated different fungicides against Phytophthora ramouram that infect different plants. Fungicides were evaluated on four genera of plants laurustinus, azalea, rhododendron and camellia. These plants were grown in green house where day time temperature was $73.5^{\circ} \mathrm{C}$ and night temperature was $51^{\circ} \mathrm{C}$. Fungi were isolated from infected samples of rhododendron collected from nurseries located in California. Leaves of experimental plants inoculated with pathogen inoculum by placing $6 \mathrm{~mm}$ plugs on wounded area. After development of lesions plants were treated with fungicides having different mode of action. Results show that different fungicides have different effect on different experimental plants. Residual effects of fungicides were also measured in this study.

Moayedi et al. [10] evaluated the antagonistic properties of Trichoderma spp. to control the root rot of sugar beet caused by Phytophthora spp. in Iran. For isolation of Trichoderma samples were collected from sugar beet field of Faris province. For isolation of Phytophthora spp. sample were collected from infected field. drechsleri and cryptogea were isolated. There were eight species of biocontrol agent that were tested against these pathogens. Different species of biocontrol agents were different in their ability to inhibit pathogen. In dual culture technique T. harzianum and T. atroviride were more efficient. In green house experiment $\mathrm{T}$. harzianum strain was best to control disease. In addition to this experiment volatile and non-volatile metabolites were also tested against mycelial growth of pathogen.

Jagtap GP [11] evaluated different bioagent and plant extract to manage citrus gummosis caused by sp. in Maharashtra state of India. Neem, Acacia, Eucalyptus, Mehendi, Dhatura, Glyricida and Lantana were used for plant extracts. Leaves were collected from healthy plants, chopped into small pieces and ground with equal quantity of distilled water. Homogenised mixture obtained was filtered by using watman filter paper number 1 . It was added in PDA at the rate of 5\% and autoclaved for 15-20 minutes at 15 Ibs Antagonistic properties of Trichoderma viridi, T. harzianum, T. lignorum, T. hamatum and Pseudomonas fluorescens were assessed. Among the plant extract lantana gave best results and eucalyptus give least. Among bio control agents T. harzianum was best in colony inhibition that was more than $90 \%$. 
Graham et al. [12] discussed success and challenges in managing diseases of citrus. Most serious disease was gummosis also known as foot rot in which pathogen infect scion near ground level. Damping off seedling also caused by spp. in which young seedling died. This pathogen also spoils the fruit by causing fruit brown rot. There are losses of $3-6 \%$ due to this pathogen. For management of diseases use disease resistant root stock, budding enough above the ground, planting well above the ground and proper drainage. In case of tolerant root stock effective fungicides would also be used. In mature groves proper drainage and use of effective fungicide is recommended to manage diseases. To manage brown rot of fruit use of phosphate fungicide before the appearance of early symptoms and after infection copper-based fungicides are good to use.

Cwalina Ambroziak B [13] conducted three-year field experiments to evaluate the effect of different chemical and biocontrol agent, on early potato cultivar health status. Different treatment consisted of different concentrations of biocontrol agent and chemicals were applied for three growing season. Before applying these concentrations in fields in vitro experiments were conducted to check the compatibility of biocontrol agent with chemicals. These experiments revealed the abilities of these treatments to control early and late blight of potato.

Mihajlovic M [14] discussed management of soil inhabiting pathogens. There is several soil borne pathogens that cause important economic losses. There are several method to manage these pathogens that are: crop rotation, use of chemicals, soil amendment, use of biological control agents, organic and inorganic mulches, soil solarisation, use of biochar, hydroponic technique for plant growth, use of resistant cultivars, soil fumigation and integrated disease management.

Adaskave JE [15] studied new mode of action and potassium phosphate resistance to manage citrus diseases caused by Phytophthora spp. in United States. Pathogen was isolated from infected fruit with brown rot symptoms, and was collected from orchard in California. Under Lab conditions, dilution method was used to asses sensitivity of potassium phosphate against pathogen at different EC value. For preharvest treatment, chemical sprayed 10 days before harvesting, after harvesting fruits were incubated with citrophthora and incubated at $20^{\circ} \mathrm{C}$ for eight days. Post-harvest treatments were applied after 8- 24 hours of inoculation with pathogen. Results indicated that both pre and post-harvest treatments gave significant control over disease control.

\section{Conclusion}

Phytophthora spp. causes most serious and economically important diseases of citrus. Tree and crop production losses occur from nursery to fruit production. Disease caused by spp. are root rot, gummosis and brown rot of fruit. Most important species involve in citrus decline are $P$. citropathora and $P$. nicotianae. Management of these diseases is necessary to reduce yield losses as well as to maintain fruit quality.

\section{Acknowledgement}

The authors are thankful to the support provided by Higher Education Commission, Islamabad, Pakistan for funding the project (No. 20-3559/NRPU/R\&D/HEC/14/1156) for Department of Plant Pathology, College of Agriculture, University of Sargodha, Sargodha.

\section{References}

1. Khan A, Iram S, Rasool A (2015) Pathogens identification and characterization that compromised citrus fruit quality in selected orchards of Sargodha. Journal of Environmental Science and Toxicology $3(4): 54-59$.

2. Lacirignola C, D'ongyi AM (2009) The Mediterranean citriculture productions and perspectives. Citrus tristeza virus and Toxopteracitricidus a serious threat to the Mediterranean citrus industry (Options Méditerranéennes: Série B. Etudes et Recherches) (65): 13-17.

3. Misachi J (2017) The World's Top Citrus Producing Countries.

4. Baghurst K (2003) The health benefits of citrus fruits. Horticulture Australia.

5. Fernando WGD, Linderman RG (1994) Chemical control of stem and root rot of cowpea caused by Phytophthora vignae. Plant disease 78(10): 967-971.

6. Lamour KH, Daughtrey ML, Benson DM, Hwang J, Hausbeck MK (2003) Etiology of Phytophthora drechsleri and P. nicotianae (= P. parasitica) diseases affecting floriculture crops. Plant disease 87(7): 854-858.

7. Wagner S, Kaminski K (2008) Evaluation of fungicides for control of Phytophthora ramorum In: Susan JF, John TK, Katharine MP tech. coords. Proceedings of the sudden oak death third science, pp. 481482.

8. Hu JH, Hong CX, Stormberg EL, Moorman GW (2008) Mefenoxam sensitivity and fitness analysis of Phytophthora nicotianae isolates from nurseries in Virginia USA. Plant Pathology 57(4): 728-736.

9. Tjosvold SA, Koike ST, Chambers DL (2008) Evaluation of fungicides for the control of Phytophthora ramorum infecting Rhododendron Camellia Pieris and Viburnum Plant Health Progress, p. 13.

10. Moayedi G, Ghalamfarsa RM (2011) Antagonistic activities of Trichoderma spp on Phytophthora root rot of sugar beet. Iran Agricultural Research 29(2): 21-38.

11. Jagtap GP, Thosar RU, Dey U (2012) Evaluation of plant extracts and bioagents for the control of gummosis of mandarin orange (Citrus reticulata blanko) caused by Phytophthora species. African Journal of Agricultural Research 7(32): 4553-4558.

12. Graham J, Feichtenberger E (2015) Citrus Phytophthora diseases Management challenges and successes. Journal of Citrus Pathology 2(1).

13. Ambroziak BC, Damszel MM, Sobieraj MG (2015) The effect of biological and chemical control agents on the health status of the very early potato cultivar Rosara. Journal of Plant Protection Research 55(4): 389-395.

14. Mihajlović M, Rekanovic E, Hrustić J, Grahovac M, Tanović B (2017) Methods for management of soilborne plant pathogens. Pestic Phytomed (Belgrade) 32(1): 9-24.

15. Adaskave JE, Förster H, Hao W, Gray M (2017) Potassium Phosphite Resistance and New Modes of Action for Managing Phytophthora Diseases of Citrus in the United States. In: Deising HB, Fraaije B, Mehl A, Oerke EC, Sierotzki H, et al. (Eds.), Modern Fungicides and Antifungal Compounds 8: 205-210 


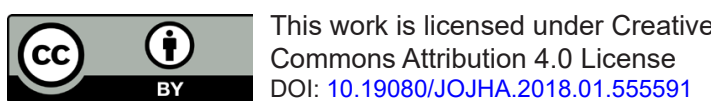

